\title{
Distinguishing between three modern Ellobius species (Rodentia, Mammalia) and identification of fossil Ellobius from Kaldar Cave (Iran) using geometric morphometric analyses of the first lower molar
}

\author{
Iván Rey-Rodríguez, Julie Arnaud, Juan-Manuel López-García, \\ Emmanuelle Stoetzel, Christiane Denys, Raphaël Cornette, and Behrouz Bazgir
}

\begin{abstract}
Ellobius remains are common and often abundant in southeastern Europe, western and central Asia archaeological sites. A correct identification of species is crucial for our understanding of the evolution of species and communities through time, including biostratigraphic sequences to be established.

This study applies geometric morphometric methods (GMM) to Ellobius first lower molars, with the objectives: 1) to discriminate modern species and explore morphological and size differences in reference samples; and 2) to identify fossil specimens recovered in archaeological sites, based on the aforementioned analysis. The reference dataset used in this paper includes specimens belonging to the three species that today occur in the southeastern Europe, western and central Asia: Ellobius fuscocapillus, E. lutescens and E. talpinus. The archaeological material comes from Late Pleistocene Iranian site of Kaldar Cave (Khorramabad valley, Lorestan Province, western Iran).

Our study shows that the shape of the anterior cap and the arrangement of the following triangles allow discriminating the three studied extant Ellobius species. The shapes of E. fuscocapillus and E. lutescens $\mathrm{m} 1$ appear rather similar, whereas Ellobius talpinus is well separated from these two species. The total length and the anterior cap of $\mathrm{m} 1$ in E. fuscocapillus is greater than in Ellobius lutescens.

The GMM analyses performed on the modern reference dataset allowed us to identify fossil specimens from Kaldar Cave as Ellobius lutescens and some as E. fuscocapillus, and excluding E. talpinus.
\end{abstract}

Iván Rey-Rodríguez. HNHP UMR 7194, CNRS / Muséum national d'Histoire naturelle / UPVD / Sorbonne

Rey-Rodríguez, Iván, Arnaud, Julie, López-García, Juan-Manuel, Stoetzel, Emmanuelle, Denys, Christiane, Cornette, Raphaël, and Bazgir, Behrouz. 2021. Distinguishing between three modern Ellobius species (Rodentia, Mammalia) and identification of fossil Ellobius from Kaldar Cave (Iran) using geometric morphometric analyses of the first lower molar. Palaeontologia Electronica, 24(1):a01. https://doi.org/10.26879/1122

palaeo-electronica.org/content/2021/3265-ellobius-and-gmm

Copyright: January 2021 Paleontological Society.

This is an open access article distributed under the terms of Attribution-NonCommercial-ShareAlike 4.0 International (CC BY-NC-SA 4.0 ), which permits users to copy and redistribute the material in any medium or format, provided it is not used for commercial purposes and the original author and source are credited, with indications if any changes are made.

creativecommons.org/licenses/by-nc-sa/4.0/ 
Universités, Musée de l'Homme, Palais de Chaillot, 17 place du Trocadéro, 75016 Paris, France. Sezione di Scienze Preistoriche e Antropologiche, Dipartimento di Studi Umanistici, Università degli Studi di Ferrara, C.so Ercole I d'Este, 32 - 44121 Ferrara, Italy. ivanreyrguez@gmail.com Julie Arnaud. Sezione di Scienze Preistoriche e Antropologiche, Dipartimento di Studi Umanistici, Università degli Studi di Ferrara, C.so Ercole I d'Este, 32 - 44121 Ferrara, Italy. rndjmr@unife.it Juan-Manuel López-García. Institut Català de Paleoecologia Humana i Evolució Social (IPHES). Zona Educacional 4, Campus Sescelades URV (Edifici W3) 43007 Tarragona, Spain. Área de Prehistòria, Universitat Rovira i Virgili. Facultat de Lletres, Avinguda Catalunya 35, 43002 Tarragona, Spain. jmlopez@iphes.cat Emmanuelle Stoetzel. HNHP UMR 7194, CNRS / Muséum national d'Histoire naturelle / UPVD / Sorbonne Universités, Musée de l'Homme, Palais de Chaillot, 17 place du Trocadéro, 75016 Paris, France. emmanuelle.stoetzel@mnhn.fr Christiane Denys. ISYEB UMR 7205, CNRS / Muséum national d'Histoire naturelle / UPMC / UA/ EPHE / Sorbonne Universités, Paris, France. christiane.denys@mnhn.fr Raphaël Cornette. ISYEB UMR 7205, CNRS / Muséum national d'Histoire naturelle / UPMC / EPHE / Sorbonne Universités, Paris, France. raphael.cornette@mnhn.fr Behrouz Bazgir. Área de Prehistòria, Universitat Rovira i Virgili. Facultat de Lletres, Avinguda Catalunya 35, 43002 Tarragona, Spain. behrouz.urv@gmail.com

Keywords: Rodentia; Arvicolinae; m1 shape; multivariate analysis; Pleistocene

Submission: 20 August 2020. Acceptance: 28 December 2020.

\section{INTRODUCTION}

This study focuses on three species of the vole genus Ellobius (Rodentia, Cricetidae, Arvicolinae) nowadays occurring in Iran, and on fossil material from Late Pleistocene Kaldar Cave site in the Zagros mountains. This region is a key area for human evolution and lies at the conjunction of potential migration routes between Africa, Europe and eastern Asia. A well-based characterization of the palaeoenvironmental context is crucial for a good understanding of human occupations (subsistence, cultural adaptations, site occupations, territory, and resource management, dispersal events, etc.). Small mammals may serve as good palaeoenvironmental and palaeoclimatic indicators of the surroundings of an archaeological site. Moreover, voles (arvicolines) in particular are commonly used in Quaternary biostratigraphy because of their rapid evolution and their abundance in the fossil record.

Ellobius is an interesting vole genus since its Pleistocene distribution reached North Africa (Stoetzel, 2013) and the southern Levant (Weissbrod and Weinstein-Evron, 2020), where it is absent now. Nowadays it occurs in southeastern Europe, western and central Asia (e.g., Rey-Rodríguez et al., 2020). It is often abundant in Middle Eastern archaeological sites, and has biostratigraphic potential for this region.
However, the identification of fossil Ellobius material is not yet elaborated satisfactory. The identification of most Ellobius specimens in museums collections is based on criteria which is usually not applicable to fragmented fossil material. Previous studies on Ellobius have mainly focused on chromosomes (Romanenko et al., 2007, 2018, 2020; Coşkun, 2016) and species discrimination based on external characters, not applicable to fossils (Gharkheloo, 2003; Kryštufek and Vohralík, 2009; Tesakov, 2016). In the archaeological literature, taxonomic attributions are often restricted to Ellobius sp. (e.g., Maul et al., 2015; Weissbrod and Weinstein-Evron, 2020).

The most common and diagnostic element in fossil vole samples are the teeth, in particular the first lower molars (m1). However, in Ellobius m1s morphological differences are hard to find, and there are apparently broad overlaps between the species (Maul et al., 2015; Kandel et al., 2017; Weissbrod et al., 2017).

With the geometric morphometric methods (GMM), fine morphological differences can be detected and variations in shape and size can be quantified, which would have been undetectable by conventional approaches, such as linear measurements or morphotype scores (Adams et al., 2009; Kaya et al., 2018). Previous GMM analyses of various fossil rodent groups (e.g., Microtus spp. Cucchi et al., 2014; Luzi et al., 2019; Meriones spp. 
Stoetzel et al., 2017; and Rattus spp. Hulme-Beaman et al., 2018) provided more comprehensive identifications compared to conventional investigations.

The purpose of this study is to investigate morphological and size differences between three species of the genus Ellobius from Iran and to apply the results to specimens of the archaeological site of Kaldar Cave. With this article we hope to demonstrate the potential of the GMM approach to the Ellobius genus and discuss its use in combination with other morphological criteria.

\section{THE GENUS ELLOBIUS FISCHER, 1814}

\section{Distribution and Ecological Remarks of the Extant Ellobius Species}

Nowadays, the genus Ellobius Fischer, 1814, occurs in southeast Europe, western and central Asia with five species (Coşkun, 2001, 2016; Wilson et al., 2017, Kaya et al., 2018): E. talpinus (Pallas, 1770), E. tancrei Blasius, 1884, E. alaicus Vorontsov et al., 1969, E. fuscocapillus (Blyth, 1843) and E. lutescens Thomas, 1897. These fossorial species inhabit steppes, grasslands and semi-deserts, and are highly adapted to subterranean life (Kryštufek and Vohralík, 2009; Coşkun, 2016).

In Iran, where the Kaldar Cave is located and the fossil material under study come from, Ellobius is currently represented by $E$. lutescens, $E$. fuscocapillus and E. talpinus (Gharkheloo, 2003; Firouz, 2005; Kryštufek and Vohralík, 2009; Kryštufek and Shenbrot, 2016; Rusin, 2017).

Ellobius lutescens (western mole vole) is distributed in northwestern Iran, Iraq, Azerbaijan, Armenia and eastern Anatolia (Thomas, 1905; Ellerman and Morrison-Scott, 1951; Darlington, 1957; Osborn, 1962; Walker, 1964; Lay, 1967; Hassinger, 1973; Roberts, 1977; Corbet, 1978; Corbet and Hill, 1991; Coşkun, 1997; Nowak, 1999; Wilson and Reeder, 2005; Kryštufek and Shenbrot, 2016; Wilson et al., 2017). In Iran, this species is found in mountain grasslands, sandy semi-deserts and steppe areas (Kryštufek and Shenbrot, 2016; Tesakov, 2016).

Ellobius fuscocapillus (southern mole vole) shows a range across northeastern Iran, Turkmenistan, Afghanistan and Pakistan. In Iran it is found in open steppes with loose soil (Gharkheloo, 2003; Shenbrot et al., 2016).

Ellobius talpinus (northern mole vole) is distributed in southeastern Ukraine and Russia, Kazakhstan, Uzbekistan, Turkmenistan and in the small part of northern Iran. Its habitat requirements are similar to that of Ellobius lutescens (Rusin, 2017).

The geographical areas occupied by the three species show differences in mean annual temperatures and precipitations (Table 1). Ellobius talpinus is found in regions with drier conditions and lower maximum annual temperature than that of the other two species. The geographic ranges of $E$. fuscocapillus and E. lutescens display similar temperatures, but E. fuscocapillus occurs in wetter environments. All the temperatures and precipitation levels are estimations, consistent with the above-described type of habitat. However, since their subterranean life makes them relatively insensitive to high variations in surface temperatures and precipitations, we can consider that all three species have essentially the same habitat requirements. What can make differences is the resulting vegetation cover, which is of course important for the survival of the animals. But all what we can assume in the current state of knowledge is that the Ellobius species provide significant information as indicators for steppe environments. Further studies are needed to evaluate more precisely the potential of the different Ellobius species as palaeoenvironmental and palaeoclimatic indicators.

\section{Fossil Record of Ellobius}

Arvicolines are commonly used in Quaternary

TABLE 1. Ranges of month precipitations and mean annual temperatures within the geographic distribution area of various Ellobius species (https://eol.org/).

\begin{tabular}{lcc}
\hline & $\begin{array}{c}\text { Temperature } \\
\text { (Max/Min) }\end{array}$ & $\begin{array}{c}\text { Precipitation } \\
\text { (mm per month) }\end{array}$ \\
\hline E. fuscocapillus & $11.62 / 0.1^{\circ} \mathrm{C}$ & 36.01 \\
E. lutescens & $10.79 / 0.1^{\circ} \mathrm{C}$ & 28.17 \\
E. talpinus & $4.75 / 0.1^{\circ} \mathrm{C}$ & 24.94 \\
\hline
\end{tabular}

biostratigraphy because of their rapid evolution and their abundance in the fossil record. The genus Ellobius may represent a crucial biostratigraphic yardstick in the Zagros mountain range, which marks the western limits of its extant distribution range in the western Asia (Weissbrod and Weinstein-Evron, 2020). However, the palaeobiogeographic and stratigraphic range of the genus in this region is still debated.

Remains of cf. Ellobius have been reported in early Pliocene (Ruscinian) sites in Kotovka, Odessa in the Ukraine (Nesin and Nadachowski, 
2001), and in two late Pliocene (Late Villanyian) sites, in the west of Ukraine and in Rivoli Veronese, northeastern Italy (Sala et al., 1994). However, Tesakov (1998) believes that the Ellobius record from Italy belongs to Ungaromys dehmi.

According to several authors (compiled in Topachevsky and Rekovets, 1982; Maul and Markova, 2007; Tesakov, 2016), there was a succession of several Ellobius species during the early Pleistocene in Eastern Europe: E. paleotalpinus, E. melitopoliensis, E. primigenis, E. lakhutensis, E. tauricus, E. kujalnikensis and E. tarchancutensis. The morphology of $E$. tarchancutensis suggests that it could be the ancestor of $E$. lutescens (Topachevsky and Rekovets, 1982; Tesakov, 2016).

In western Asia, Ellobius has been recognized in several Middle Pleistocene archaeological sites in Sel'-Ungur in Kyrgyzstan (Ellobius ex gr. tancrei; Markova, 1992), in Hummal layer G in Syria (Ellobius sp.; Maul et al., 2015), Azokh-1 units Vm, Vu, III, II/III, II (Ellobius sp.; Fernández-Jalvo, 2016) in Nagorno Karabakh and Krasarin (Ellobius (Bramus) pomeli; Tesakov, 2016).

During the Middle Pleistocene, Ellobius extended its range westwards to Israel, Tabun C and D (Bate, 1937; Frumkin and Comay, in press), Misliya Cave (Weissbrod and Weinstein-Evron, 2020) and North Africa as far as to the Moroccan Atlantic coast (Jaeger, 1988; Stoetzel, 2013). It probably arrived there from western Asia via the Libyco-Egyptian route during a cooling and aridification of North Africa favouring the development of steppes at the beginning of the Middle Pleistocene (Stoetzel, 2013). The North African species then evolved independently from the Asian ones, through the succession of $E$. africanus, E. atlanticus, E. barbarus and E. zimae (Jaeger, 1988). In most studies, it is concluded that Ellobius, outside its current range, disappeared at the end of the Middle Pleistocene at the latest (Stoetzel, 2013; Maul et al., 2015; Weissbrod and Weinstein-Evron, 2020).

In the Late Pleistocene, Ellobius trancrei has been described from the Mousterian site of OgzyKichik, Tadzhikistan (Markova, 1992). The modern species E. lutescens was found in Iraq (Bate, 1930) in the layers of Hazar Merd, dated to 25,000 years ago (Coşkun, 2016). Hashemi et al. (2006) noted that remains of $E$. lutescens have been found in several Late Pleistocene and early Holocene sites in western and northwestern Iran: Kani Mikaeil (Kordestan), Qalaloun near Kouhdasht, Yafteh Gar, and Arjeneh near Khoramabad (Lor- estan). Ellobius lutescens has also been documented in Upper Palaeolithic and Neolithic units of Dzudzuana Cave (Georgia, 34.4-6 ka cal BP; Belmaker et al., 2016), and also in Aghitu-3 level VII (Armenia, Upper Palaeolithic, 39-36 ka cal BP; Kandel et al., 2017). Ellobius sp. has been described in Azokh-1 unit I (157 \pm 26 ka BP) and in the Holocene site Azokh-5 (Nagorno Karabakh, Parfitt, 2016).

\section{Description of Tooth Morphology}

We restricted our analysis to the first lower molar, the most diagnostic tooth in arvicolines. The Ellobius lower $\mathrm{m} 1$ is composed of the anterior cap $(A C)$, five triangles $(T)$ with three buccal (BRA) and four lingual (LRA) re-entrant angles, and one posterior lobe $(\mathrm{PL})$ (Figure 1A). Ellobius molars are notably characterized by broadly confluent triangles, and the presence of roots that are visible in adult and old individuals (Figure 1B). Moreover, Ellobius molars lack cement in the re-entrant angles (Coşkun, 2016).

For modern representatives, the skull morphology (Kaya et al., 2018) and external characters (Kryštufek and Vohralík, 2009) contain the main diagnostic features, whereas fossil samples mostly consist of isolated molars or broken jaws. The occlusal morphology of the lower $\mathrm{m} 1$ is rather similar in the various Ellobius species (especially the three Iranian species E. fuscocapillus, E. Iutescens and E. talpinus). However, some specific morphological characters have been pointed out in previous studies: the AC is broad in Ellobius lutescens, narrow in Ellobius talpinus and elongated in Ellobius fuscocapillus (Maul et al., 2015); the distance between T4 and T5 (W) and the total length (L) differ between the species, Ellobius fuscocapillus showing the largest teeth and Ellobius talpinus the smallest (Rey-Rodríguez et al., 2020). However, these varying morphological and biometric characters are not always clear nor reliable distinction is possible.

\section{MATERIAL AND METHODS}

\section{Modern and Fossil Material Studied}

For this study we compared modern reference collections and fossil material of Ellobius using dental morphometric markers, because teeth represent the most abundant and diagnostic elements in fossil assemblages (Stoetzel et al., 2017). A total of 111 first lower molars (m1s) were measured. In our analysis, we took into account the individual age of the specimens using the classification of 


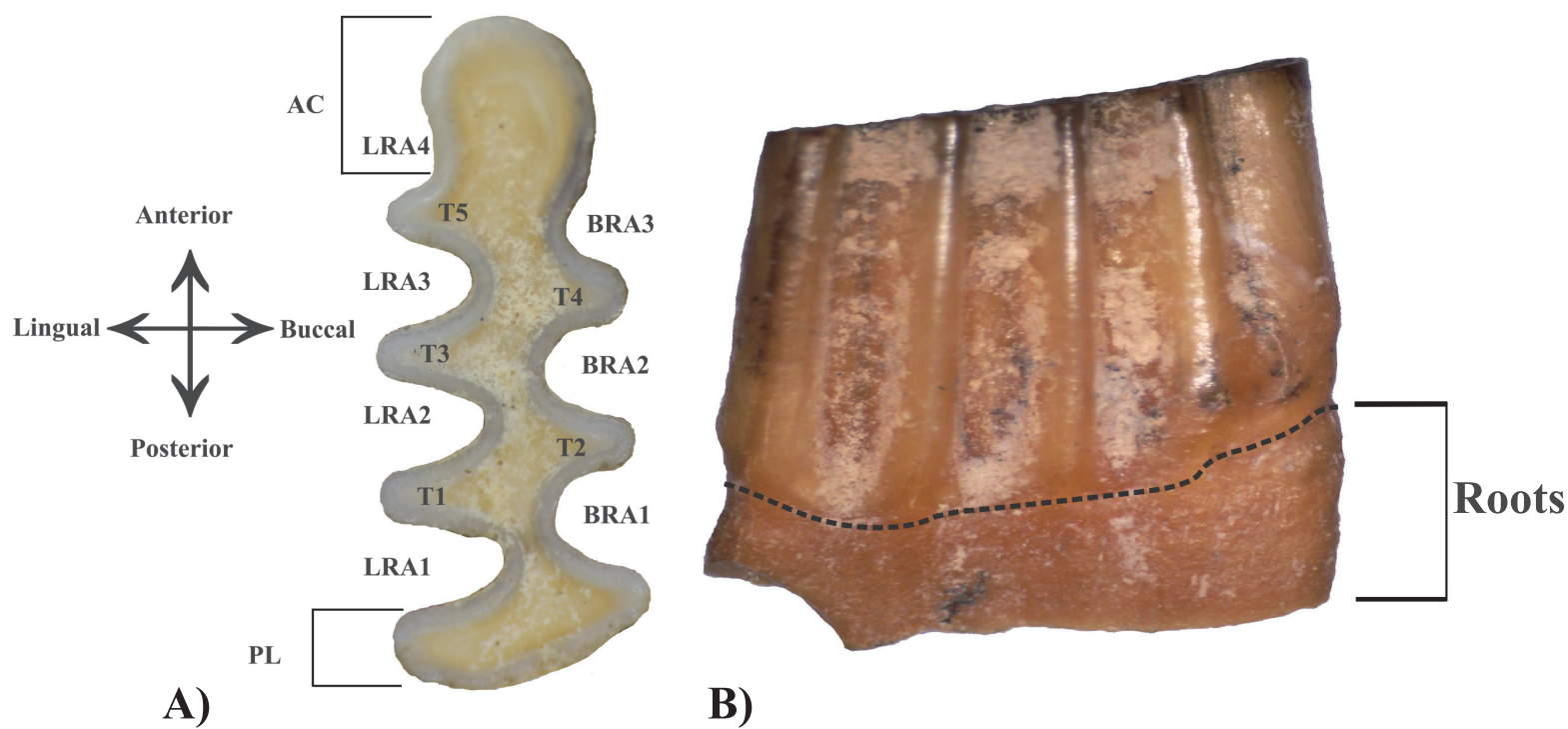

FIGURE 1. A) Occlusal surface of Ellobius right lower $\mathrm{m} 1$ : triangle ( $\mathrm{T}$ ); buccal re-entrant angle (BRA); lingual reentrant angle (LRA); anterior cap (AC); posterior lobe (PL); B) Lingual view of left lower m1.

Coşkun (2016). We observed a striking difference in the occlusal pattern between young and old individuals, so we only used adult individuals, in order to avoid any bias (Stoetzel et al., 2017). Damaged and/or digested molars were not considered. In the reference collections, both males and females were used because no significant sexual dimorphism is known for Ellobius (Gharkheloo, 2003). Figure 2 shows the most frequent morphotypes of the three extant and fossil analysed species.

We used specimens from the modern reference collections of the Natural History Museum of London (NHM), the Field Museum of Chicago (FM) and the American Museum of Natural History of New York (AMNH) (Table 2); all the specimens were captured in the field, not bred in captivity.

The archaeological samples come from the Iranian site of Kaldar Cave (Table 2), located in the Zagros Mountains, in the northern part of Khorramabad Valley, Lorestan Province, western Iran (Becerra-Valdivia et al., 2017) (Figure 3). The material is hosted at the Institut Català de Paleoecologia Humana i Evolució Social (IPHES, Tarragona, Spain). More information on the archaeological context and the discoveries from this site can be found in Bazgir et al $(2014,2017)$ and Rey-Rodríguez et al. (2020).

The study material comes from Layer 5 (attributed to the Middle Palaeolithic) and Layer 4 (attributed to the Upper Palaeolithic) (Bazgir et al., 2014, 2017; Rey-Rodríguez et al., 2020). A total of 264 minimum number of individuals were identified from the small-mammal assemblages of Kaldar Cave. Layers 4 and 5 are dominated by Microtus spp. (60 individuals in Layer 4 and 79 in Layer 5), followed by Ellobius spp. (18 individuals in Layer 4 and 17 in Layer 5) and Meriones cf. persicus (17 individuals in Layer 4 and 18 in Layer 5). Other species were found in lesser proportions: Chionomys nivalis, Cricetulus migratorius, Mesocricetus brandti, Allactaga sp., Myomimus sp. These species indicate that the environment in the area was mainly composed of open dry and steppe areas. However, we also found Apodemus sp. which are related rather to a dense vegetation cover (including trees/bush), as well as few remains of Mus cf. musculus in both Layers 4 and 5 . In this cave, there are also other levels, as Layers 1-3, that did not yield enough material to draw palaeoclimatic inferences $(\mathrm{MNI}<30)$. All the species identified at Kaldar Cave still occur in the area today (ReyRodríguez et al., 2020).

Small-mammal remains were collected in the field by water screening, using superimposed 5 and $0.5-\mathrm{mm}$ mesh screens. In subsequent years $(2018,2019)$, the sediment was sorted by hand and under microscope in order to identify and count the small-mammal elements and extract Ellobius remains for the present study.

\section{Data Acquisition}

The Ellobius lower molars were all photographed under constant conditions with a digital camera (Canon EOS 700D) coupled with a binocu- 

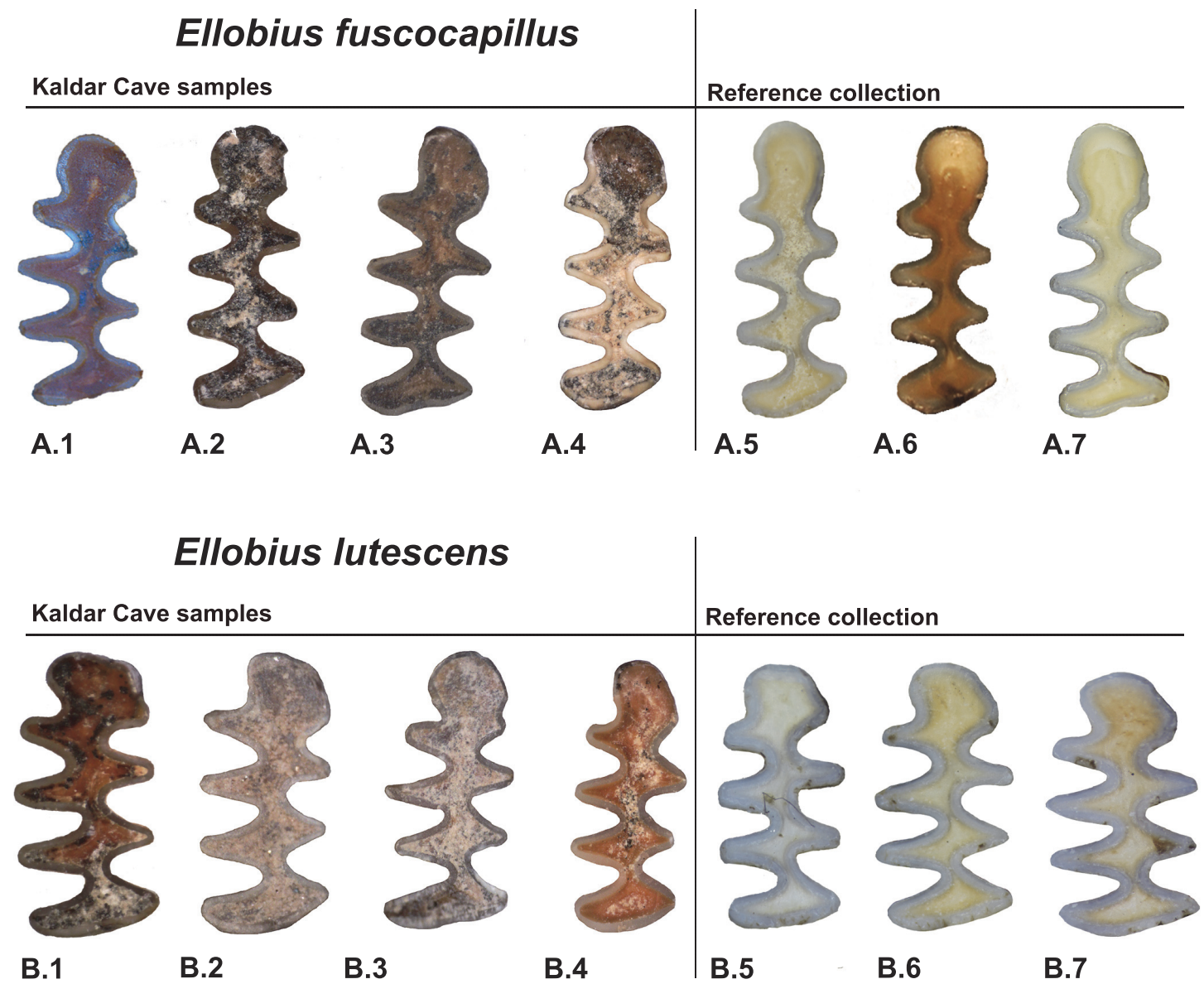

\section{Ellobius talpinus}

Reference collection

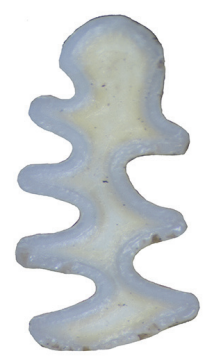

C. 1

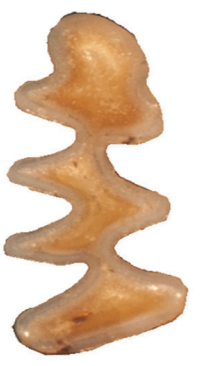

C.2

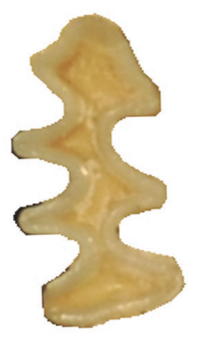

C.3

FIGURE 2. Ellobius lower m1s (all figured as right ones) from the extant reference collections and Kaldar Cave. A) Ellobius fuscocapillus: A.1-Kaldar Cave, 2014/4/SL5II/E6/125-130, right lower m1, number 157. A.2-Kaldar Cave, 2014/4/SL5/E5/109-111, right lower m1, number 520. A.3-Kaldar Cave, 2014/5/SL7II/E7/170-180, right lower m1, number 104. A.4- Kaldar Cave, 2014/5/SL7II/F6/135-145, right lower m1, number 547.A.5-modern, NHM86101513, Afghanistan, right lower m1. A.6-modern, FM111846, Iran, right lower m1. A.7-modern, NHM86101512, Afghanistan, right lower m1; B) Ellobius lutescens: B.1-Kaldar Cave, 2014/5/SL7II/F6/130-140, right lower m1, number 319. B.2Kaldar Cave, 2014/4/SL5II/F7/115-118, right lower m1, number 90. B.3- Kaldar Cave, 2014/4/SL5II/F7/115-118, right lower m1, number 91. B.4- Kaldar Cave, 2014/5/SL7II/E7/145-150, right lower m1, number 436. B.5-modern, NMH916416, Turkey, right lower m1. B.6-modern, NMH916414, Turkey, right lower m1. B.7-modern, NMH916412, Turkey, right lower m1; C) Ellobius talpinus: C.1-modern, NHM3421126, Russia, right lower m1. C.2-modern, FM103163, Afghanistan, right lower m1. C.3-modern, AMNH59797, Mongolia, right lower m1. Scale $1 \mathrm{~mm}$. 
TABLE 2. Modern reference collection for each museum specimen. Natural History Museum of London (NHM), Field Museum of Chicago (FM) and American Museum of Natural History of New York (AMNH). Archaeological specimens from Kaldar Cave, MP = Middle Palaeolithic, UP = Upper Palaeolithic.

\begin{tabular}{|c|c|c|c|c|}
\hline \multicolumn{5}{|c|}{ Reference collection } \\
\hline Right lower m1 & NHM & AMNH & FM & Total \\
\hline Ellobius fuscocapillus & 6 & - & 34 & 40 \\
\hline Ellobius lutescens & 6 & - & - & 6 \\
\hline Ellobius talpinus & 7 & 11 & 20 & 38 \\
\hline Total & 19 & 11 & 54 & 84 \\
\hline \multicolumn{5}{|c|}{ Kaldar Cave } \\
\hline Right lower m1 & \multicolumn{2}{|c|}{ Level 5(MP) } & Level 4(UP) & Total \\
\hline Ellobius fuscocapillus & \multicolumn{2}{|c|}{1} & 1 & 2 \\
\hline Ellobius lutescens & \multicolumn{2}{|c|}{6} & 2 & 8 \\
\hline Total & \multicolumn{2}{|c|}{7} & 3 & 10 \\
\hline Left lower m1 & \multicolumn{2}{|c|}{ Level 5(MP) } & Level 4(UP) & Total \\
\hline Ellobius fuscocapillus & \multicolumn{2}{|c|}{4} & 2 & 6 \\
\hline Ellobius lutescens & \multicolumn{2}{|c|}{4} & 7 & 11 \\
\hline
\end{tabular}

lar microscope (Leica M125). All the pictures of the first lower molars were taken in occlusal view, and right molars were used; when they were not available (only in the fossil material), the left lower molars were used and successively mirrored before the positioning of the landmarks and semilandmarks. A scale bar was included in all the photographs in order to facilitate the extraction of a scaling factor, which can be used to estimate the centroid size (Tabatabaei Yazdi and Alhajeri, 2018). We took into account the lateral side for the age classification.

To investigate the first lower molar size and shape we combined two-dimensional (2D) landmarks (LM) and semi-landmarks (SLM) on the pho- tographs using TPSdig2 v.2.32 software package (Rohlf, 2016) for 2D geometric morphometric analyses (we include our data on a TPS file, Appendix 1). The methodology was adapted from the previous studies of Klenovšek and Kryštufek (2013), Cucchi et al. (2014, 2017), Cornette et al. (2015), Maul et al. (2015), Kryštufek et al. (2016), Stoetzel et al. (2017) and Dianat et al. (2017, 2020).

Fourteen landmarks were placed at the maximum curvature on the salient and re-entrant lingual and buccal angles, on the posterior lobe and the anterior cap, where the landmarks were positioned on the outline (Figure 4A).

In order to characterize the size and shape of the anterior cap, 60 equidistant semi-landmarks

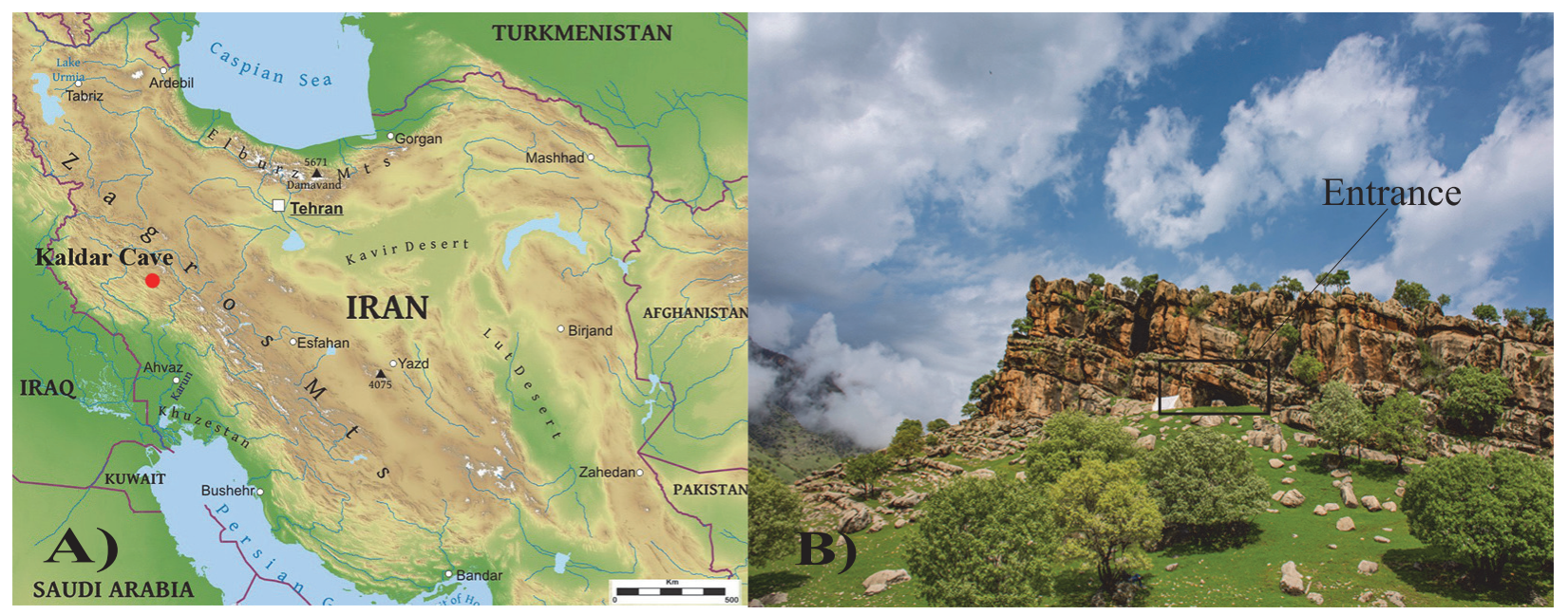

FIGURE 3. A) Kaldar Cave location. B) Entrance from the south of Kaldar Cave. 


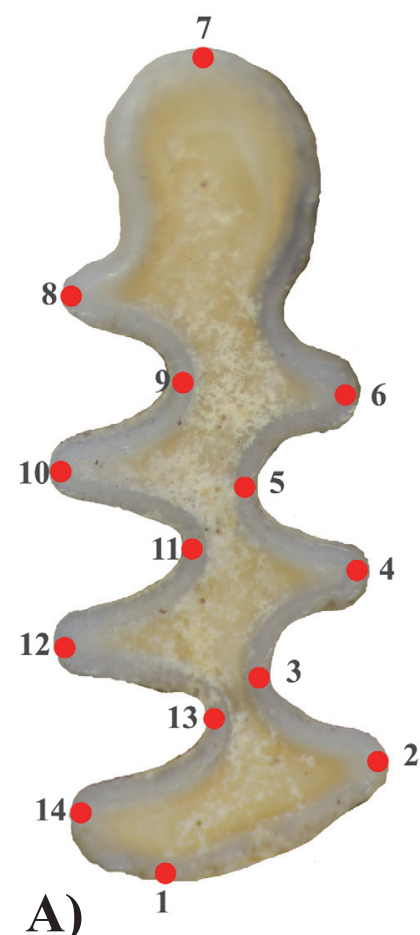

A)
B)

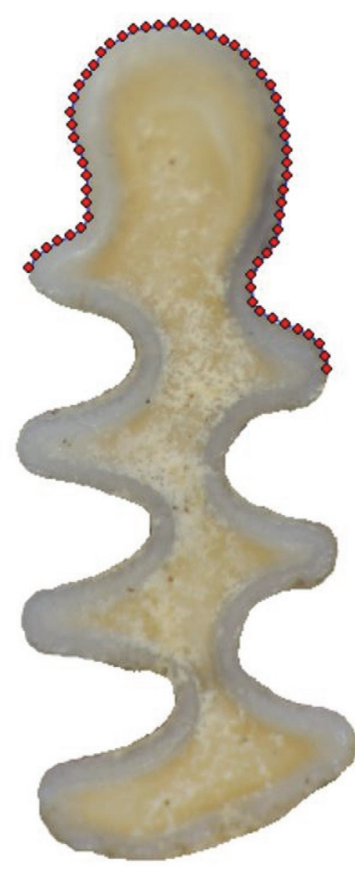

FIGURE 4. Ellobius right lower $\mathrm{m} 1$. A) 14 landmarks: Landmarks on the outermost turning point of buccal $(2,4,6)$ and lingual $(8,10,12,14)$ salient angles, and on the innermost turning point of buccal $(3,5)$ and lingual $(9,11,13)$ reentrant angle. B) 60 semi-landmarks on the anterior cap.

were automatically positioned along the curve corresponding to the external outline of the tooth enamel from buccal salient angle 3 to lingual salient angle 4 (Figure 4B).

To test the repeatability of the procedure, we re-digitized the set of landmarks and semi-landmarks 10 times on three randomly selected teeth. We estimate the measurement error on this new set of variables from the Procrustes ANOVA mean squares following the method proposed by Fruciano (2016). The procedure has been retained highly repeatable $(R=0.97)$.

\section{Shape Analyses}

All the following analyses were performed with R ( $R$ Core Team, 2020) using the Geomorph (Adams et al., 2020) and Morpho (Schlager, 2017) packages.

Before undertaking the statistical analysis, the 2D landmark and semi-landmark coordinates were scaled through a general Procrustes analysis (GPA), allowing the semi-landmarks to slide along the outline (Gunz and Mitteroecker, 2013). A principal component analysis (PCA) was then performed on the new normalized landmark and semi-landmark coordinates of the reference collection.
Archaeological specimens were added a posteriori as supplementary individuals in the PCA shape space. A canonical variate analysis (CVA) was then performed on the PC scores, keeping $90 \%$ of the overall shape variation (Baylac and Frieß, 2006). To assess the classification accuracy, a cross-validation test was performed on the CVA scores. Finally, the allometric effect was investigated through univariate and multivariate linear regression of the PC scores on the log of the centroid size.

\section{RESULTS}

The PCA (Table 3) performed on the normalized landmarks and sliding semi-landmarks of the first lower molar reveals significant differences between the analysed species, the first two principal components (PCs) account for $52.7 \%$ of the total variance (Figure 5). Component 3 was also analysed but the variance was too low, and there was no differentiation between the species. We included the complete table with all statistical data in Appendix 2.

The main variation along the PC1 (38.2\%) regards the morphology of the Anterior Cap, which is more flattened for the positive values and more 
TABLE 3. Contribution of the first $10^{\text {th }}$ PCs to the total variance (\%). PCA: principal component analysis.

\begin{tabular}{ccccccccccc}
\hline PC & PC1 & PC2 & PC3 & PC4 & PC5 & PC6 & PC7 & PC8 & PC9 & PC10 \\
\hline$\%$ & 38.2 & 14.5 & 8.1 & 6.9 & 4.2 & 2.8 & 2.6 & 2.2 & 1.6 & 1.5 \\
\hline
\end{tabular}

rounded for the negatives ones. Ellobius talpinus occur on the positive part of the PC1 axis while $E$. fuscopapillus and E. lutescens are located on the negatives ones reflecting a broader and more rounded AC. Along the PC2 (14.5\%) scores, the positive values show an $A C$ elongated and pronounced on the buccal side, negative values display a more rounded $A C$ with a clear constriction between BRA3 and LRA4. On PC2 there is not a clear differentiation between the three species. However, E. lutescens specimens are located principally in the upper half of the E. fuscocapillus and lutescens cloud, with positive PC2 values.
The shape of Ellobius talpinus with narrower AC (Figure 5) is significantly different from that of E. fuscocapillus and lutescens, which appear morphologically very close one to another. The Kaldar Cave specimens are well distributed in the cloud of E. lutescens and E. fuscocapillus, with all of them having negative PC1 values. We can conclude that Ellobius talpinus is not present in the archaeological sample.

In order to estimate possible allometric effects on the samples, we performed a linear regression of the PCs onto the log of the centroid size (following the approach of Mitteroecker et al., 2015). Only PC1 shows a significant correlation with size $(\mathrm{R} 2=$

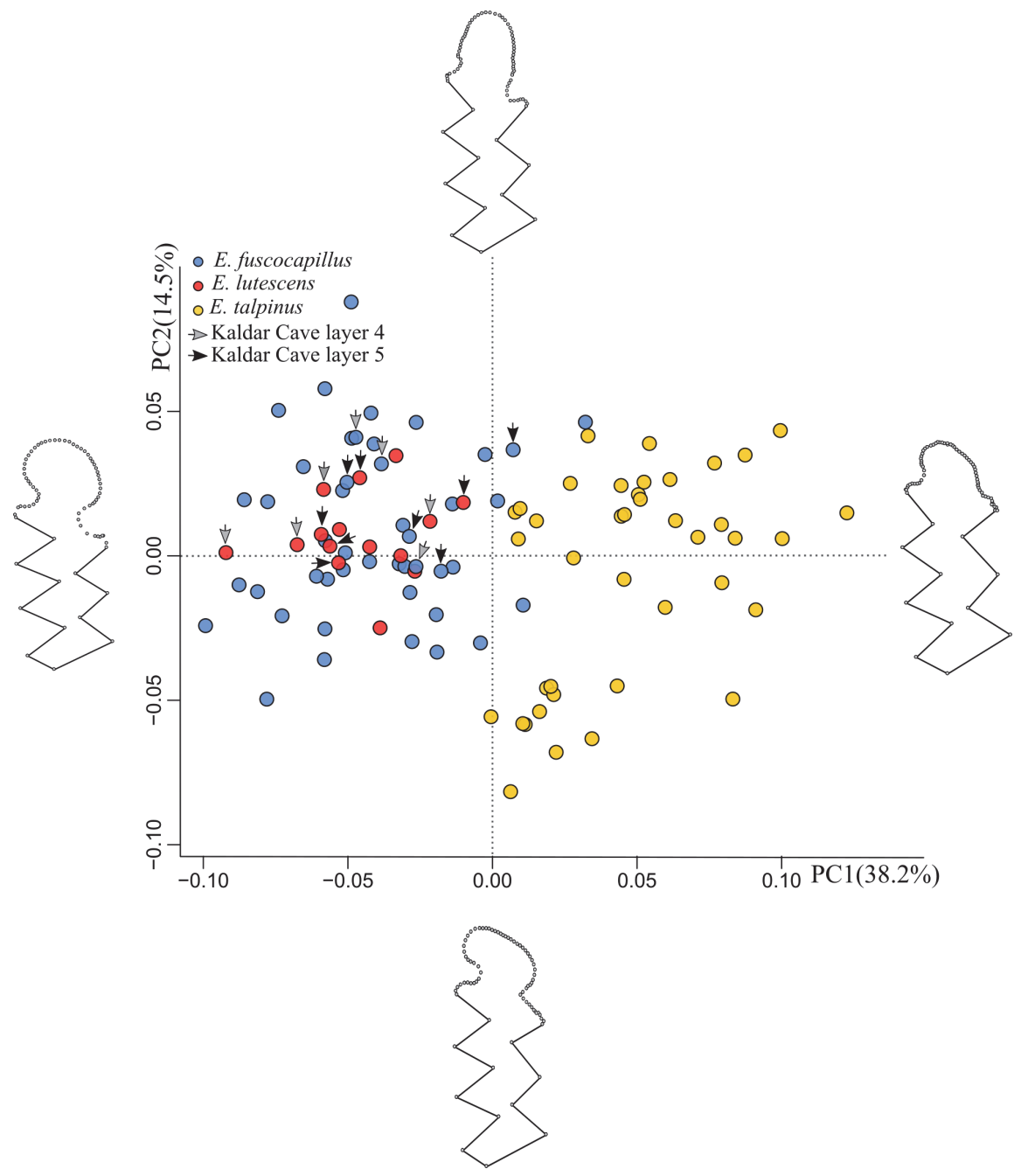

FIGURE 5. Principal component analysis on the normalized landmarks and sliding semilandmarks and shape configuration at the extreme ends of the two first PCs. 


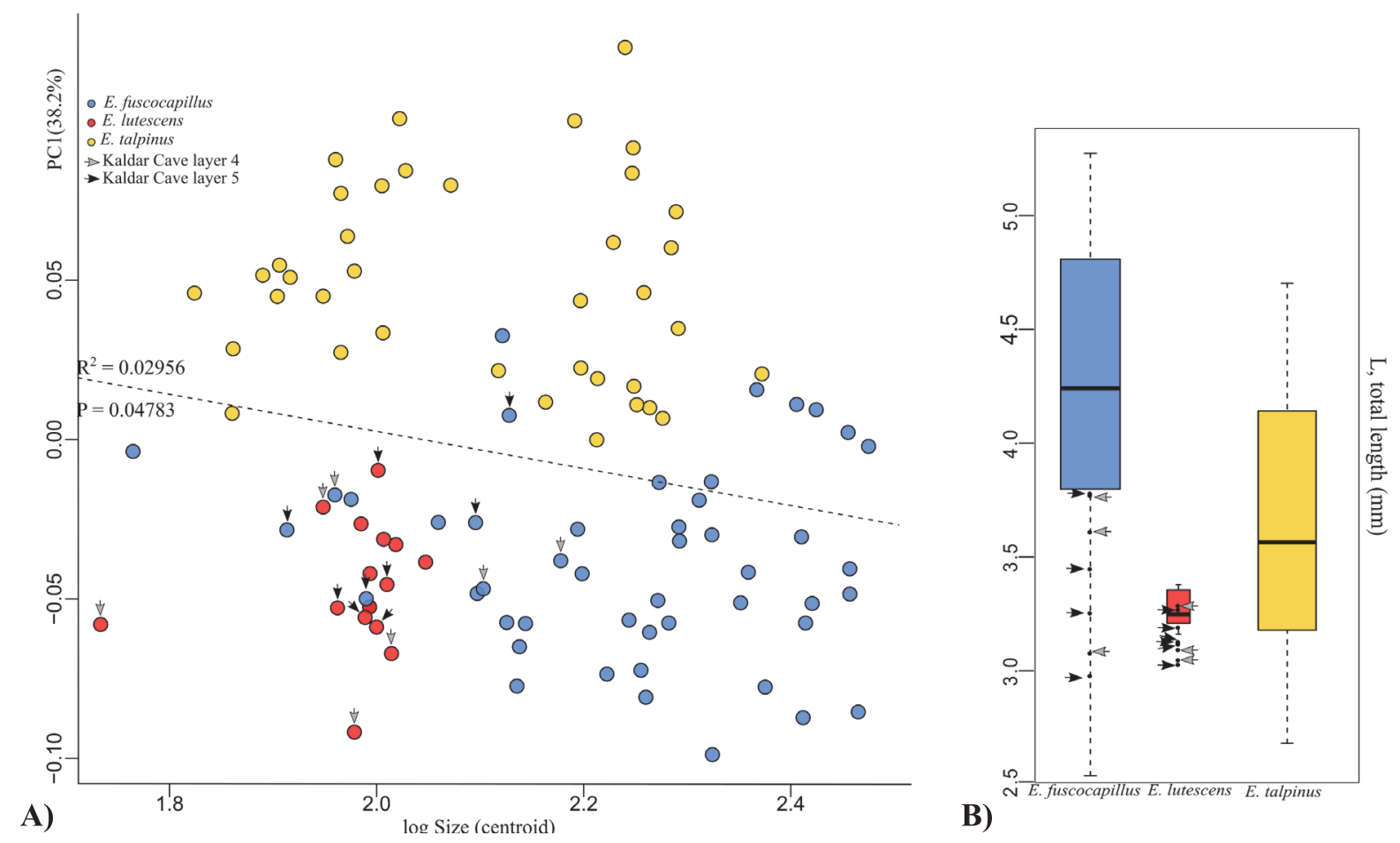

FIGURE 6. A) First two PCs from the Principal component analysis performed on the size and shape including the reference collection and Kaldar Cave material. B) Boxplot of the total length of Ellobius from the extant reference collections and Kaldar Cave.

0.02956, $p=0.04783$ ). In this graph (Figure 6A), it is possible to discriminate Ellobius lutescens from $E$. fuscocapillus, the latter showing larger dimensions. E. talpinus presents a wide size range overlapping the ranges of the two latter (Figure 6). The archaeological remains are placed again in the cloud of $E$. lutescens and $E$. fuscocapillus but with some ambiguous identifications. We have also evidenced this confusion in the reference dataset with three E. fuscocapillus individuals from the Field Museum that were replaced among $E$. lutescens in our analysis, indicating a possible misidentification of the museum specimens. On Figure 6B, Kaldar Cave fossil specimens appear in general smaller than the reference specimens, but inside the standard deviation.

The canonical variate analysis of $90 \%$ of the total variation (PCs1 to 16) in the sample and the relative cross-validation procedure give an overall classification accuracy of $86 \%$ (with almost $100 \%$ correct classification for Ellobius talpinus) (Table 4).

\section{DISCUSSION}

Our results indicate that it is possible to accurately identify Ellobius species by applying GMM to $\mathrm{m} 1$ shape and size. The main differences between species concern the AC shape, the size and the general disposition of the triangles.

One result of the performed GMM is that the shape of Ellobius fuscocapillus and E. lutescens clusters in one cloud, and E. talpinus in another. This is in agreement with the distinction of two clades among the genus Ellobius: the subgenus Bramus Pomel, 1892 (with E. fuscocapillus Blyth, 1843, and E. lutescens Thomas, 1897) and the subgenus Ellobius Fischer, 1814 (with E. talpinus

TABLE 4. Cross-validated classification results in frequencies and \%.

\begin{tabular}{lcccccccc}
\hline \multicolumn{1}{c}{ Taxon } & \multicolumn{2}{c}{ E. fuscocapillus } & \multicolumn{2}{c}{ E. lutescens } & \multicolumn{2}{c}{ E. talpinus } & \multicolumn{2}{c}{ None } \\
E. fuscocapillus & $\mathbf{N}$ & $\%$ & $\mathbf{N}$ & $\%$ & $\mathbf{N}$ & $\%$ & $\mathbf{N}$ & $\%$ \\
E. lutescens & 37 & 78.72 & 10 & 21.27 & 0 & - & 0 & - \\
E. talpinus & 2 & 13,33 & 13 & 86.66 & 0 & - & 0 & - \\
\hline
\end{tabular}


Pallas, 1770; E. tancrei Blasius, 1884; and E. alaicus Vorontsov et al. 1969) (Carleton and Musser, 2005).

The shape differences between Ellobius fuscocapillus and E. lutescens is grossly in agreement with some earlier considerations based on conventional methods. Previously, Maul et al. (2015) considered the AC shape as a discriminant criteria, being broad in Ellobius lutescens, narrow in Ellobius talpinus and elongated in Ellobius fuscocapillus. Tesakov (2016) found that the size of $E$. lutescens is slightly smaller than E. fuscocapillus. Rey-Rodríguez et al. (2020) reported that the confluence between T4 and T5 differs among the species, with T1-T2 and T3-T4 being slightly less pairwise opposed in E. lutescens.

Our GMM analyses allowed these previously examined criteria to be assessed all together, in taking into account the size, the morphology of the $\mathrm{AC}$ and the general disposition of the triangles. In our fossil samples many teeth are fragmented, and could not have been included in our GMM. However, it could be possible to consider fragments of Ellobius $\mathrm{m} 1 \mathrm{~s}$ in further analyses, for example by focusing only on the shape of the anterior cap.

\section{Sliding Semi-Landmarks and Anatomical Landmarks Compared with Previous Systematic Methods of Ellobius Identification}

Despite classic methods enable to distinguish between many $\mathrm{m} 1 \mathrm{~s}$ of some of the species, a throughout discrimination remains unclear. According to Maul et al. (2015), morphological features of the AC (without performing GMM analyses) would be enough to permit species identification, and especially to differentiate Ellobius talpinus from Ellobius lutescens and fuscocapillus, because Ellobius talpinus has a less developed and narrower $\mathrm{AC}$ than in the other two species. But in the present study, we have seen that there is a morphological overlap between E. lutescens and E. fuscocapillus. So, while "classic" morphological criteria often result in unclear features or overlaps between species, our GMM analysis of Ellobius $\mathrm{m} 1$ allowed two groups to be accurately differentiated, Ellobius talpinus on the one hand and Ellobius lutescens and fuscocapillus on the other. The distinction between these two latter species is more complex, and indeed no straightforward grouping was observed with the first PCA (Figure 5). However, morphological differences between them could have been detected by comparing the mean shapes of their $\mathrm{m} 1 \mathrm{~s}$ (Figure 7) and by including the size parameter (Figure 6).
Figure 7 shows the means (dots) and variations (arrows) of the different landmarks and semilandmarks between Ellobius fuscocapillus and $E$. lutescens. Major morphological differences are seen in points 1 (posterior lobe), 3, 4, 5 and 6 (BRAs and BSAs). This means that T1-T2 and T3T4 are less parallel in E. lutescens than in E. fuscocapillus, as observed in the buccal part. ReyRodriguez et al. (2020) proposed that the width between T4 and T5 (W) and the total length (L) of the two species are different. The configuration of the AC shows that the transition between T4-T5 is narrower in E. lutescens than in E. fuscocapillus, which generates a smaller and more closed AC in $E$. lutescens than in E. fuscocapillus, in accordance with the observations of Maul et al. (2015). Finally, also the previous observation of Tesakov (2016) is confirmed that size is a valid criterion for distinguishing Ellobius fuscocapillus (larger) and Ellobius lutescens (smaller).

Combining shape and size allowed us identifying the fossil Ellobius m1s from Kaldar Cave. The morphology of the AC, the size and the $W$ (width between T4 and T5) are valid criteria in most of the cases, but we have seen that GMM analyses allowed them all to be combined and a number of previous identifications to be re-analysed (Bazgir et al., 2014, 2017; Rey-Rodríguez et al., 2020). The results of the present analysis allowed some $E$. lutescens from the archaeological material to be re-assigned to $E$. fuscocapillus (five E. fuscocapillus, three from Layer 4 and two from Layer 5 were re- assigned). These misclassifications were due to the fact that E. fuscocapillus and E. lutescens are quite similar from a morphological point of view, and because the previous identifications were based on the $W, L$ and the $A C$, subjected to overlapping problems, which have subsequently been clarified with the GMM.

In this study we have not seen morphological differences between specimens from Layer 4 and 5. As we are working in an archaeological site, the fact that we have two species in the same levels does not mean that they were deposited at the same time. Layer 4 has a chronological range of $54,400-46,050$ cal BP at the bottom and 23,100 \pm 3,300 to $29,400 \pm 2,300 \mathrm{BP}$ at the top, so we have a gap were one species could be replaced by the other one. The same observation can be made for Layer 5 , whose chronology is still under review. Moreover, the fact that we have two species in the same levels does not mean that they lived in the exact same place, because the small mammal assemblages from Kaldar Cave were accumulated 

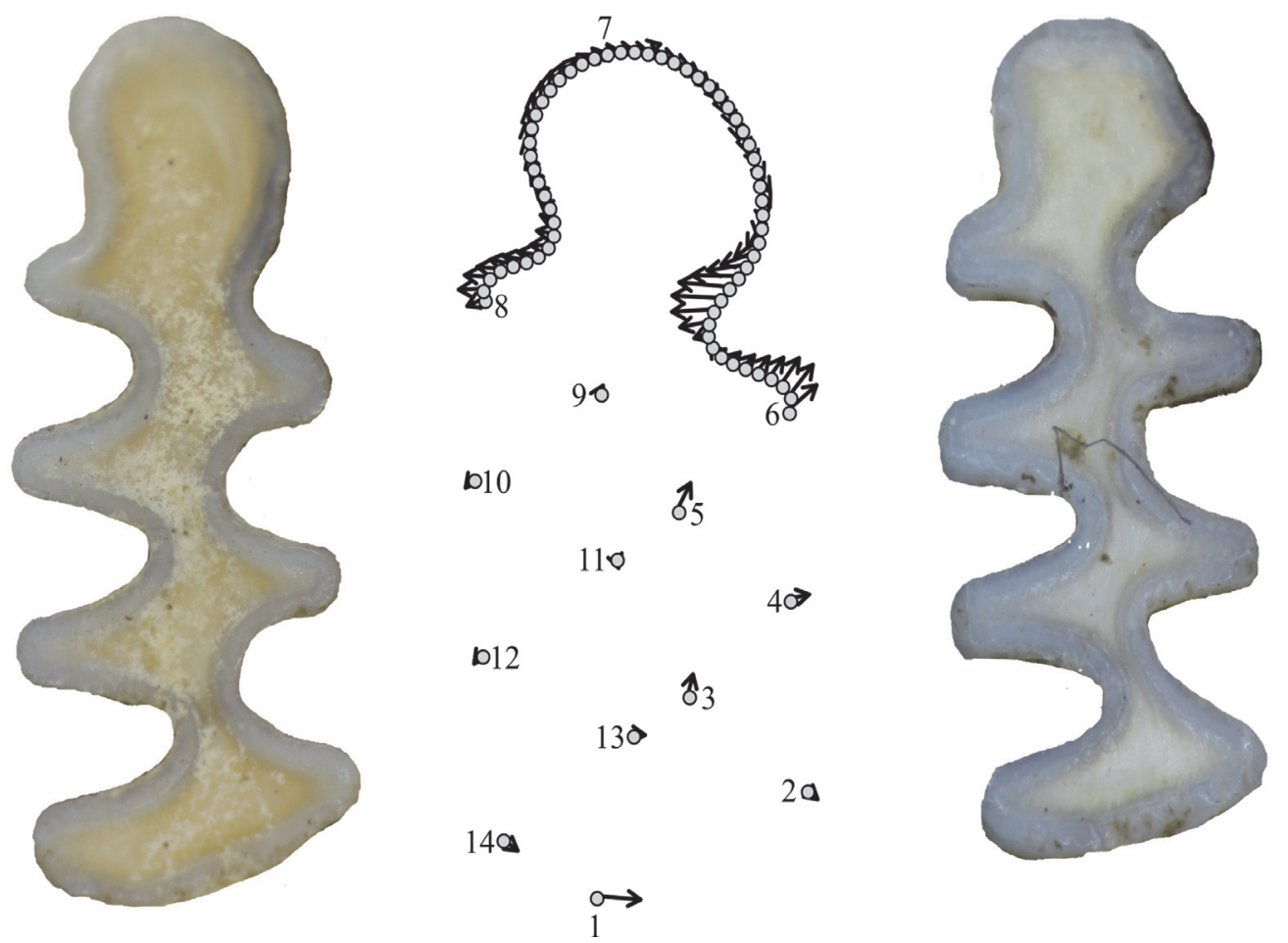

FIGURE 7. Morphological differences between Ellobius fuscocapillus (left) and Ellobius lutescens (right). Arrows depict the displacements between corresponding landmarks in the reference (dots) and Ellobius lutescens as target specimens.

by nocturnal raptors (Rey-Rodríguez et al., 2020), which could hunt in different habitats on a territory of several (tens of) $\mathrm{km}^{2}$.

Ellobius fuscocapillus is not present in the area nowadays, but it may have lived there in the past. Indeed, at Kaldar Cave, the palaeoenvironmental data (obtained with the habitat weighting method) have shown that the landscape was mainly composed of steppes in both levels, which are favorable habitats for the Ellobius species (Rey-Rodríguez et al., 2020). The absence of $E$. talpinus in our archaeological sample could be linked to the climatic requirements of the species, but this hypothesis remains to be deepened.

\section{CONCLUSIONS}

In the present study, based on modern and fossil specimens of Ellobius species, we found potential size and shape differences within the examined material thanks to GMM analyses. On the basis of the $\mathrm{m} 1$ shape alone, we were able to differentiate two groups: E. talpinus on the one hand, and E. fuscocapillus and E. lutescens on the other. Taking size into account, moreover, it was possible to distinguish $E$. fuscocapillus from $E$. lutescens. However, we agree that it would be nec- essary to increase the reference dataset, particularly for $E$. lutescens, which may help us find further discriminative patterns between these three species in future studies.

GMM enabled us to obtain good results in fossil species attributions. Here, only complete teeth were used, i.e. not the whole fossil Ellobius sample from Kaldar Cave. We obtained better results in the classifications in including all the teeth landmarks instead of the $A C$ alone. It would thus be really useful to improve the results in order to be able to identify broken or digested molars, albeit with the caveat that when only the anterior cap of the molar is preserved we cannot discriminate between $E$. fuscocapillus and E. lutescens. Accordingly, it would be necessary to combine this method with other techniques and use all the criteria together.

It would be interesting to extend this GMM study to other modern and fossil Ellobius species, especially from Middle Pleistocene sites, in order to obtain a more complex overview of their morphological differences and their evolution throughout their current and past geographic range, and to explore the potential and usefulness of this tool in the archaeological sites of southeastern Europe, western and central Asia. 


\section{ACKNOWLEDGMENTS}

Rey-Rodriguez is the beneficiary of a PhD scholarship funded by the Erasmus Mundus Program (IDQP). J.M. López-García was supported by a Ramón y Cajal contract (RYC-2016-19386) with financial sponsorship from the Spanish Ministry of Science, Innovation and Universities. This work was developed within the framework of projects 2017SGR859, 2017SGR840 and 2017SGR1040 (AGAUR, Generalitat de Catalunya), and 2018PFRURVB291 (Univ. Rovira i Virigli). We thank the head of the Research Institute of Cultural Heritage and Tourism (RICHT) (Dr. B. Omrani) and the head of the Iranian Center for Archaeological Research (ICAR) (Dr. R. Shirazi) for providing us with the necessary support and permissions in studying the materials. We thank the head of the Lorestan Cultural Heritage, Handicraft and Tourism Organization (Mr. A. Ghasemi) for all his support.
We also thank the head of International Collaboration and Ties of the RICHT (Mrs. M. Kholghi) for all her cooperation and help. B. Bazgir received his PhD scholarship from the Fundación Atapuerca, for which he is grateful. We would like to thank R. Portela Miguez, Senior Curator in Charge of Mammals, for his help with the reference collection in the Natural History Museum of London; L. Heaney, A. Ferguson and L. Smith of Chicago Field Museum; and M. Surovy, J. Galkin and C. Mehling of the American Museum of Natural History of New York. We thank A. Profico for his precious help.

We would like to thank R. Glasgow for reviewing the English language of the manuscript. We also want to thank to the Editors Dr. D. Nowakowski, Dr. D. Hembree and Dr. C. Haug, as well as the three anonymous reviewers for their comments and suggestions that strongly improved the final version of the manuscript.

\section{REFERENCES}

Adams, D.C., Collyer, M.L., and Kaliontzopoulou, A. 2020. Geomorph: software for geometric morphometric analyses. $R$ package version 3.2.1.

Adams, D.C., Rohlf, F.J.,and Slice, D.E. 2009. Geometric morphometrics: ten years of progress following the revolution. Italian Journal of Zoology, 71 (1):5-16. https://doi.org/10.1080/11250000409356545

Bate, D.M.A. 1930. Animal remains from the Dark Cave, Hazar Merd. American School of Prehistoric Research Bulletins, 6:38-41.

Bate, D.M.A. 1937. Palaeontoogy: the fossil fauna of the Wady El-Mughara caves. In Garrod, D.A.E. and Bate, D.M.A. (eds.), Excavations at the Wady El-Mughara. Clarendon Press, Oxford.

Baylac, M. and Frieß, M. 2006. Fourier descriptors, procrustes superimposition, and data dimensionality: an example of cranial shape analysis in modern human populations, p.145165. In Slice, D.E. (ed.), Modern Morphometrics in Physical Anthropology. Kluwer Academic Publishers-Plenum Publishers, New York. https://doi.org/10.1007/0-387-27614-9_6

Bazgir, B., Otte, M., Tumung, L., Ollé, A., Deo, S.G., Joglekar, P., López-García, J.M., Picin, A., Davoudi, D., and van der Made, J. 2014. Test excavations and initial results at the middle and upper paleolithic sites of Gilvaran, Kaldar, Ghamari caves and Gar Arjene Rockshelter, Khorramabad Valley, western Iran. Comptes Rendus-Palevol, 13:511-525. https://doi.org/10.1016/j.crpv.2014.01.005

Bazgir, B., Ollé, A., Tumung, L., Becerra-Valdivia, L., Douka, K., Higham, T., Van Der Made, J., Picin, A., Saladié, P., López-Garciá, J.M., Blain, H.-A., Allué, E., Fernández-Garciá, M., ReyRodríguez, I., Arceredillo, D., Bahrololoumi, F., Azimi, M., Otte, M., and Carbonell, E. 2017. Understanding the emergence of modern humans and the disappearance of Neanderthals: insights from Kaldar Cave (Khorramabad Valley, Western Iran). Scientific Reports 7:43460. https://doi.org/10.1038/srep43460

Becerra-Valdivia, L., Douka, K., Comeskey, D., Bazgir, B., Conard, N.J., Marean, C.W., Ollé, A., Otte, M., Tumung, L., Zeidi, M., and Higham, T.F.G. 2017. Chronometric investigations of the Middle to Upper Paleolithic transition in the Zagros Mountains using AMS radiocarbon dating and Bayesian age modelling. Journal of Human Evolution, 109:57-69.

https://doi.org/10.1016/j.jhevol.2017.05.011 
Belmaker, M., Bar-Yosef, O., Belfer-Cohen, A., Meshveliani, T., and Jakeli, N. 2016. The environment in the Caucasus in the Upper Paleolithic (Late Pleistocene): evidence from the small mammals from Dzudzuana cave, Georgia. Quaternary International, 425:4-15. https://doi.org/10.1016/j.quaint.2016.06.022

Blasius, W. 1884. Comptes rendus des séances de I'Académie des Sciences. Tome XCVIII. Nos 1 et 2. Paris.

Blyth, E. 1843. The Journal of the Asiatic Society of Bengal. Calcutta: Bishop's College Press, 1832-1936.

Carleton, M.D. and Musser, G.G. 2005. Order Rodentia, p. 745-752. In Wilson, D.E. and Reeder, D.M. (eds.), Mammal Species of the World, Third Edition. The Johns Hopkins University Press, Baltimore.

Corbet, G.B. 1978. The Mammals of the Palearctic Region: A Taxonomic Review. British Museum of Natural History, London.

Corbet, G.B. and Hill, J.E. 1991. A World List of Mammalian Species. 3rd ed. British Museum of Natural History, London.

Cornette, R., Stoetzel, E., Baylac, M., Moulin, S., Hutterer, R., Nespoulet, R., El Hajraoui, M.A., Denys, C., and Herrel, A. 2015. Shrews of the genus Crocidura from El Harhoura 2 (Témara, Morocco): the contribution of broken specimens to the understanding of Late PleistoceneHolocene palaeoenvironments in North Africa. Palaeogeography, Palaeoclimatology, Palaeoecology, 436:1-8. https://doi.org/10.1016/j.palaeo.2015.06.020

Coşkun, Y. 1997. Ellobius lutescens Thomas, 1897 (Rodentia: Cricetidae) Turkish Journal of Zoology. 21; 349-354.

Coşkun, Y. 2001. On distribution, morphology and biology of the mole vole, Ellobius lutescens Thomas, 1897 (Mammalia: Rodentia) in eastern Turkey. Zoology in the Middle East, 23:5-12. https://doi.org/10.1080/09397140.2001.10637861

Coşkun, Y. 2016. Review of unique odd chromosome-numbered underground rodent species of the Palearctic region: Ellobius Lutescens Thomas 1897 (Rodentia: Cricetidae). Turkish Journal of Zoology, 40:831-841. https://doi.org/10.3906/zoo-1509-53

Cucchi, T., Barnett, R., Martínková, N., Renaud, S., Renvoisé, E., Evin, A., Sheridan, A., Mainland, I., Wickham-Jones, C., Tougard, C., Quéré, J.P., Pascal, Michel, Pascal, Marine, Heckel, G., O'Higgins, P., Searle, J.B., and Dobney, K.M. 2014. The changing pace of insular life: 5000 years of microevolution in the Orkney vole (Microtus arvalis orcadensis). Evolution, 68:2804-2820. https://doi.org/10.1111/evo.12476

Cucchi, T., Mohaseb, A., Peigné, S., Debue, K., Orlando, L., and Mashkour, M. 2017. Detecting taxonomic and phylogenetic signals in equid cheek teeth: towards new palaeontological and archaeological proxies. Royal Society Open Science 4. https://doi.org/10.1098/rsos.160997

Darlington, P.J. 1957. Zoogeography: the Geographical Distribution of Animals. John Wiley and Sons, New York.

Dianat, M., Darvish, J., Aliabadian, M., Siahsarvie, R., Krystufek, B., and Nicolas, V. 2020. Systematics and evolution of the libyan jird based on molecular and morphometric data. Journal of Zoological Systematics and Evolutionary Research, 58:439-458. https://doi.org/10.1111/jzs.12335

Dianat, M., Darvish, J., Cornette, R., Aliabadian, M., and Nicolas, V. 2017. Evolutionary history of the Persian Jird, Meriones persicus, based on genetics, species distribution modelling and morphometric data. Journal of Zoological Systematics and Evolutionary Research, 55:29-45. https://doi.org/10.1111/jzs.12145

Ellerman, J.R. and Morrison-Scott, T.C.S. 1951. Checklist of Palearctic and Indian Mammals, 1780 to 1946 . British Museum of Natural History, London.

Fischer von Waldheim, G. 1814. Zoognosia tabulis synopticis illustrata: in usum praelectionum Academiae imperialis medico-chirugicae mosquensis edita. Mosquae. Typis Nicolai $\mathrm{S}$. Vsevolozsky.

Fruciano, C. 2016. Measurement error in geometric morphometrics. Development Genes and Evolution, 226:139-158. https://doi.org/10.1007/s00427-016-0537-4

Frumkin, A. and Comay, O. In press. The last glacial cycle of the southern Levant: Paleoenvironment and chronology of modern humans. Journal of Human Evolution 2019:102609. https://doi.org/10.1016/j.jhevol.2019.04.007

Gharkheloo, M.M. 2003. A study on the morphology, karyology and distribution of Ellobius Fischer, 1814 (Mammalia: Rodentia) in Iran. Turkish Journal of Zoology, 27:281-292. 
Gunz, P. and Mitteroecker, P. 2013. Semilandmarks: a method for quantifying curves and surfaces. Hystrix, 24:103-109.

Hassinger, J.D. 1973. A survey of the mammals of Afghanistan: resulting from the 1965 Street Expedition (Excluding Bats). Fieldiana Zoology, 60. https://doi.org/10.5962/bhl.title.3065

Hashemi, N., Darvish, J., Mashkour, M., and Biglari, F. 2006. Rodents and lagomorphs remains from late Pleistocene and early Holocene Caves and Rochshelter sites in the Zagros region, Iran. Iranian Journal of Animal Biosystematics, 2:25-33.

Hulme-Beaman, A., Cucchi, T., Evin, A., Searle, J.B., and Dobney, K. 2018. Exploring Rattus praetor (Rodentia, Muridae) as a possible species complex using geometric morphometrics on dental morphology. Mammalian Biology, 92:62-67. https://doi.org/10.1016/j.mambio.2018.04.002

Jaeger, J.J. 1988. Origine et evolution du genre Ellobius (Mammalia, Rodentia) en Afrique NordOccidentale. Folia Quaternaria 57:3-50.

Kandel, A.W., Gasparyan, B., Allué, E., Bigga, G., Bruch, A.A., Cullen, V.L., Frahm, E., Ghukasyan, R., Gruwier, B., Jabbour, F., Miller, C.E., Taller, A., Vardazaryan, V., Vasilyan, D., and Weissbrod, L. 2017. The earliest evidence for Upper Paleolithic occupation in the Armenian Highlands at Aghitu-3 Cave. Journal of Human Evolution, 110:37-68. https://doi.org/10.1016/j.jhevol.2017.05.010

Kaya, A., Gharkheloo, M.M., and Coşkun, Y. 2018. Geographic variation in the skull morphology of Ellobius lutescens Thomas, 1897 (Mammalia: Rodentia) by geometric morphometric analyses. Vertebrate Zoology, 68:157-164.

Klenovšek, T. and Kryštufek, B. 2013. An ontogenetic perspective on the study of sexual dimorphism, phylogenetic variability, and allometry of the skull of European ground squirrel, Spermophilus citellus (Linnaeus, 1766). Zoomorphology, 132:433-445. https://doi.org/10.1007/s00435-013-0196-1

Kryštufek, B. and Shenbrot, G. 2016. Ellobius lutescens. The IUCN Red List of Threatened Species 2016: e.T7655A22340006. https://doi.org/10.2305/IUCN.UK.20162.RLTS.T7655A22340006.en

Kryštufek, B. and Vohralík, V. 2009. Mammals of Turkey and Cyprus, Rodentia II: Cricetinae, Muridae, Spalacidae, Calomyscidae, Capromyidae, Hystricidae, Castoridae. ZALOŽBA ANNALES, University of Primorska. https://doi.org/10.1644/10-MAMM-R-221.1

Kryštufek, B. and Vohralík, V. 2009. Mammals of Turkey and Cyprus, Rodentia II: Cricetinae, Muridae, Spalacidae, Calomyscidae, Capromyidae, Hystricidae, Castoridae. ZALOŽBA ANNALES, University of Primorska.

Kryštufek, B., Janžekovič, F., Hutterer, R., and Klenovšek, T. 2016. Morphological evolution of the skull in closely related bandicoot rats: a comparative study using geometric morphometrics. Hystrix, 27:1-7. https://doi.org/10.4404/hystrix-27.2-11639

Lay, D.M. 1967. A study of the mammals of Iran, resulting from the street expedition of 1962-63. Fieldiana Zoology, 54:168-171.

Luzi, E., Pazonyi, P., and López-García, J.M. 2019. The influence of climate on morphometric traits of fossil populations of Microtus arvalis and $M$. agrestis from the Carpathian Basin, northern Hungary. Lethaia, 52:123132. https://doi.org/10.1111/let.12294

Markova, A. 1992. Fossil rodents (Rodentia, Mammalia) from the Sel'-Ungur Acheulian cave site (Kirghizstan). Acta Zoologica Cracoviensia, 35 (2):217-239.

Maul, L.C. and Markova, A.K. 2007. Similarity and regional differences in Quaternary arvicolid evolution in Central and Eastern Europe. Quaternary International, 160:81-99. https://doi.org/10.1016/j.quaint.2006.09.010

Maul, L.C., Smith, K.T., Shenbrot, G., Bruch, A.A., Wegmüller, F., and Le Tensorer, J.M. 2015. Microvertebrates from unit G/layer 17 of the archaeological site of Hummal (EI Kowm, Central Syria): preliminary results. Anthropologie, 119:676-686. https://doi.org/10.1016/j.anthro.2015.10.010

Michaux, J., Reyes, A., and Catzeflis, F. 2001. Evolutionary history of the most speciose mammals: molecular phylogeny of muroid rodents. Molecular Biology and Evolution, 18:2017-2031. https://doi.org/10.1093/oxfordjournals.molbev.a003743

Mitteroecker, P., Windhager, S., Müller, G.B., and Schaefer, K. 2015. The morphometrics of "masculinity" in human faces. PLoS ONE, 10. https://doi.org/10.1371/journal.pone.0118374

Nesin, V. and Nadachowski, A. 2001. Late Miocene and Pliocene small mammal faunas (Insectivora, Lagomorpha, Rodentia) of Southeastern Europe. Acta Zoologica Cracoviensia, 44:107-135. 
Nowak, R.M. 1999. Walker's Mammals of the World. The Johns Hopkins University Press, Baltimore.

Osborn, D.J. 1962. Rodents of subfamily Microtinae from Turkey. Journal of Mammology, 43 (4):515-529. https://doi.org/10.2307/1376914

Pallas, P. S. 1770. Spicilegia zoologica quibus novae imprimis et obscurae animalium species iconibus, descriptionibus atque commentariis illustrantur. Fasciculus octavus.

Parfitt, S. A. 2016. Rodents, lagomorphs and insectivores from Azokh Cave, p.163-177. In Fernández-Jalvo, Y., King, T., Yepiskoposyan, L., and Andrews, P. (eds.), Azokh Cave and the Transcaucasian Corridor. Springer, Dordrecht. https://doi.org/10.1007/978-3-319-24924-7

R Core Team, 2020. R: A language and environment for statistical computing. R Foundation for Statistical Computing. http://www.r-project.org/index.html

Rey-Rodríguez, I., Lopez-Garcia, J.M., Blain, H.-A., Stoetzel, E., Denys, C., Bazgir, B., and Ollé, A. 2020. Exploring the landscape and climatic conditions of Neanderthals and anatomically modern humans in the Middle East: the rodent assemblage from the late Pleistocene of Kaldar Cave (Khorramabad Valley, Iran). Quaternary Science Reviews, 236:106278. https://doi.org/10.1016/j.quascirev.2020.106278

Roberts, T.J. 1977. The Mammals of Pakistan. Ernst Benn Ltd., London.

Rohlf, F.J. 2016. tpsDig, Digitize Landmarks and Outlines, Version 2.32. Department of Ecology and Evolution, State University of New York at Stony Brook, New York.

Romanenko, S.A., Fedorova, Y.E., Serdyukova, N.A., Zaccaroni, M., Stanyon, R., and Graphodatsky, A.S. 2020. Evolutionary rearrangements of $X$ chromosomes in voles (Arvicolinae, Rodentia). Scientific Reports, 10:13235. https://doi.org/10.1038/s41598-020-70226-4

Romanenko, S.A., Sitnikova, N.A., Serdukova, N.A., Perelman, P.L., Rubtsova, N. V., Bakloushinskaya, I.Y., Lyapunova, E.A., Just, W., Ferguson-Smith, M.A., Yang, F., and Graphodatsky, A.S. 2007. Chromosomal evolution of Arvicolinae (Cricetidae, Rodentia). II. The genome homology of two mole voles (genus Ellobius), the field vole and golden hamster revealed by comparative chromosome painting. Chromosome Research, 15:891897. https://doi.org/10.1007/s10577-007-1171-9

Romanenko, S.A., Serdyukova, N.A., Perelman, P.L., Trifonov, V.A., Golenishchev, F.N., Bulatova, N.S., Stanyon, R., and Graphodatsky, A.S. 2018. Multiple intrasyntenic rearrangements and rapid speciation in voles. Scientific Reports, 8:14980. https://doi.org/10.1038/s41598-018-33300-6

Rusin, M. 2017. Ellobius talpinus, Northern Mole Vole. The IUCN Red List of Threatened Species 2016:e.T7656A115085720. https://doi.org/10.2305/IUCN.UK.2016-3.RLTS.T7656A22339917.en

Sala, B., Masini, F., and Torre, D. 1994. Villanyian arvicolids from Veronese, a karst fissure in the Adige valley, Northeastern Italy. Bolletino Societa Paleontologica Italina, 33:3-11.

Schlager, S. 2017. Morpho and Rvcg shape analysis, p. 217-256. In Zheng,G., Li, S., and Szekely, G. (ed.), Statistical Shape and Deformation Analysis. Academic Pres, London.

Shenbrot, G., Kryštufek, B., and Molur, S. 2016. Ellobius fuscocapillus, Southern Mole Vole. The IUCN Red List of Threatened Species 2016:e.T7654A22339730. https://doi.org/10.2305/IUCN.UK.2016-2.RLTS.T7654A22339730.en

Stoetzel, E. 2013. Late Cenozoic micromammal biochronology of northwestern Africa. Palaeogeography, Palaeoclimatology, Palaeoecology, 392:359-381. https://doi.org/10.1016/j.palaeo.2013.09.026

Stoetzel, E., Cornette, R., Lalis, A., Nicolas, V., Cucchi, T., and Denys, C. 2017. Systematics and evolution of the Meriones shawii/grandis complex (Rodentia, Gerbillinae) during the Late Quaternary in northwestern Africa: exploring the role of environmental and anthropogenic changes. Quaternary Science Reviews, 164:199-216. https://doi.org/10.1016/j.quascirev.2017.04.002

Tabatabaei Yazdi, F. and Alhajeri, H. 2018. Sexual dimorphism, allometry, and interspecific variation in the cranial morphology of seven Meriones species (Gerbillinae, Rodentia). Hystrix, Italian Journal of Mammalogy, 29(2):162-167.

Tesakov, A. S. 1998. Voles of the Tegelen fauna. Mededelingen Nederlands Instituut voor Toegepaste Geowetenschappen TNO, 60:71-134

Tesakov, A.S. 2016. Early Middle Pleistocene Ellobius (Rodentia, Cricetidae, Arvicolinae) from Armenia. Russian Journal of Theriology, 15(2):151-158. 
Thomas, O. 1897. Ellobius lutescens. The Annals and Magazine of Natural History, 20:308.

Thomas, O. 1905. Ellobius woosnami. Abstract Proceedings of the Zoological Society, 23:526.

Vorontsov, N.N., Lyapunova, E.A., Zakaryan, G.G., and Ivanov, V.G. 1969. The karyology and taxonomy of the genus Ellobius (Microtinae, Rodentia),p.127-129. In Vorontsov, N.N. (ed.) The Mammals (Evolution, Karyology, Taxonomy, Fauna).Nauka ,Novosibirsk, Moscow (in Russian).Topachevsky, V.A. and Rekovets, L.I. 1982. New material to the systematics and evolution of mole voles of the nominative subgenus of the genus Ellobius (Rodentia, Cricetidae). Vestnik Zoologii, 5:47-74 (in Russian).

Vorontsov, N.N., Lyapunova, E.A., Zakaryan, G.G., and Ivanov, V.G. 1969. The karyology and taxonomy of the genus Ellobius (Microtinae, Rodentia), p.127-129. In Vorontsov, N.N. (ed.), The Mammals (Evolution, Karyology, Taxonomy, Fauna), Nauka, Novosibirsk, Moscow (in Russian).

Walker, E.P. 1964. Mammals of the World. Vol. 2. The Johns Hopkins Press, Baltimore.

Weissbrod, L., Marshall, F.B., Valla, F.R., Khalaily, H., Bar-Oz, G., Auffray, J.-C., Vigne, J.-D., and Cucchi, T. 2017. Origins of house mice in ecological niches created by settled huntergatherers in the Levant 15,000 y ago. Proceedings of the National Academy of Sciences, 114:4099-4104. https://doi.org/10.1073/pnas.1619137114

Weissbrod, L. and Weinstein-Evron, M. 2020. Climate variability in early expansions of Homo sapiens in light of the new record of micromammals in Misliya Cave, Israel. Journal of Human Evolution, 139:102741. https://doi.org/10.1016/j.jhevol.2020.102741

Wilson, D.E. and Reeder, D.M. 2005. Mammal Species of the World. Smithsonian Institution Scholarly Press, Washington D.C.

Wilson, D.E., Mittermeier, R.A., and Lacher, T.E. 2017. Handbook of the Mammals of the World. Volume 7. Rodents II. Lynx Edicions, Barcelona, Spain. 


\section{APPENDICES}

\section{APPENDIX 1.}

TPS data. The appendix material is available online as a zipped file at https://palaeo-electronica.org/content/2021/3265-ellobius-and-gmm.

\section{APPENDIX 2.}

Complete statistical data for the PCA. The appendix material is available online as a zipped file at https://palaeo-electronica.org/content/2021/3265-ellobius-and-gmm. 